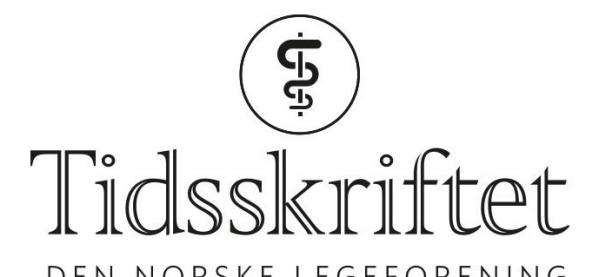

DEN NORSKE LEGEFORENING

\title{
Prestisjetung pris for forskning på biologisk variasjon
}

FRA ANDRE TIDSSKRIFTER

ØYVIND STOPLE SIVERTSEN

Tidsskriftet

Norske forskere har ledet arbeidet med å utvikle en standard for kvalitetsvurdering av studier om biologisk variasjon.

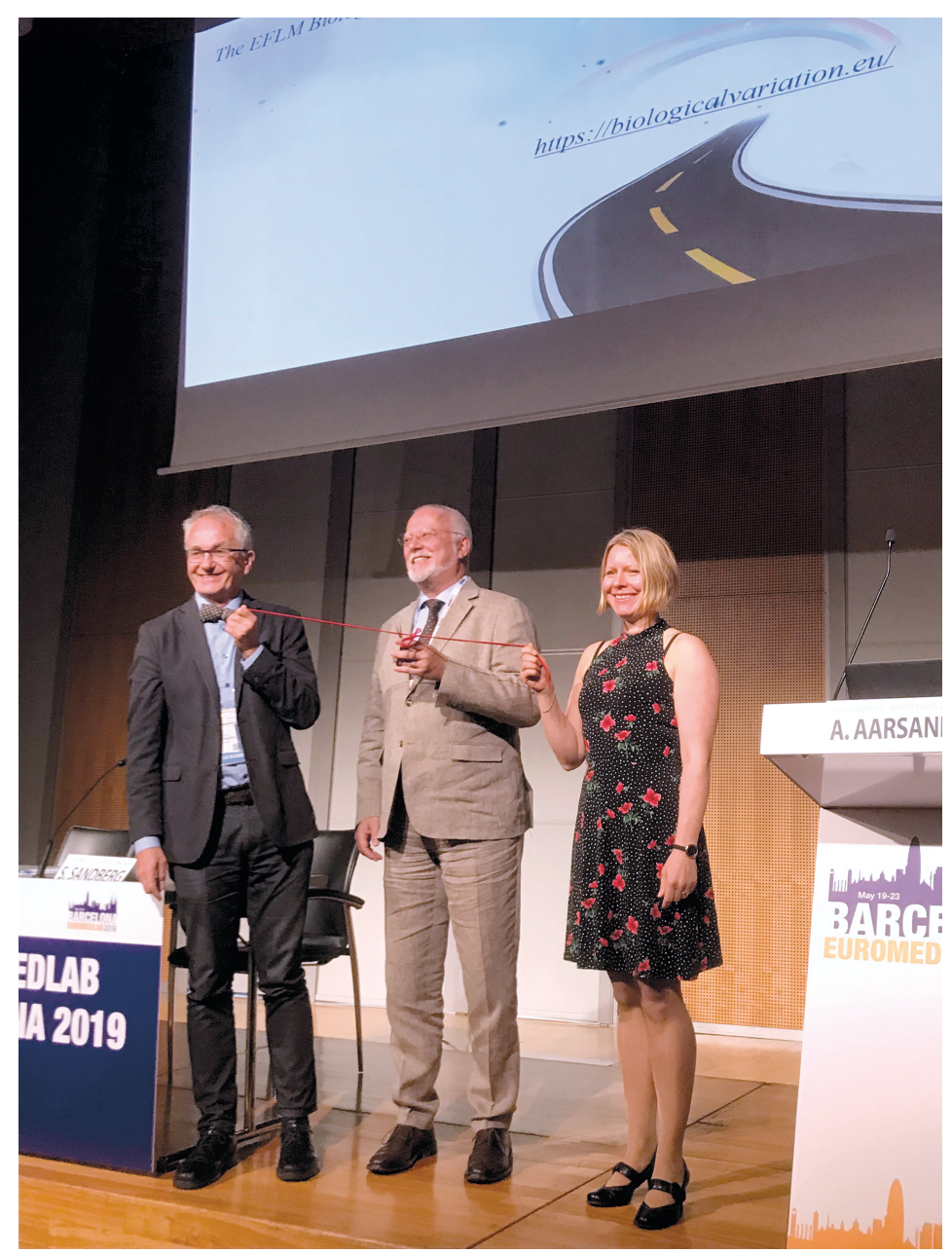

Fra venstre, Sverre Sandberg leder av European Federation of Laboratory Medicine and Clinical Chemistry (EFLM) Task Group on the Biological Variation Database, Michael Neumaier president $i$ EFLM og Aasne K. Aarsand, leder av EFLM Working Group on BIological Variation. Foto: European Federation of Laboratory Medicine and Clinical Chemistry 
En arbeidsgruppe ledet av Aasne K. Aarsand ved Norsk kvalitetssikring av laboratorievirksomhet (Noklus) og Haukeland universitetssjukehus har utviklet en standard for kvalitetsvurdering av studier på biologisk variasjon og hvordan slike studier bør utføres. Arbeidet ble i 2018 publisert i tidsskriftet Clinical Chemistry (1). Forfatterne mottok nylig en prestisjetung pris fra European Federation of Laboratory Medicine and Clinical Chemistry (EFLM).

- Data på biologisk variasjon benyttes til en rekke formål innenfor laboratoriemedisin, forteller Aarsand.

- Endringer i analyseresultater kan blant annet skyldes naturlig biologisk variasjon eller sykdom. Estimat på biologisk variasjon brukes blant annet til å sette mål for hvilken kvalitet analyseinstrument i laboratoriene skal ha. Det er imidlertid stor variasjon i biologisk variasjonsdata rapportert for samme analyse, og det har vært stilt spørsmål ved kvaliteten på en del av dataene som benyttes, sier hun.

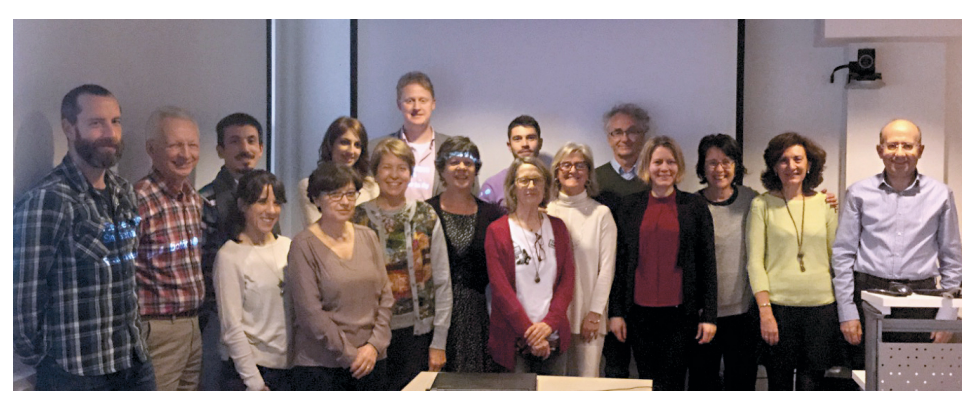

Fra venstre: Thomas Røraas, Bill Bartlett, Fernando Marques Garcia, Zoraida Corte, Margarita Simon, Elisabet González, Carmen Ricos, Niels Jonker, Carmen Perich, Jorge Diaz-Garzò, Virtues Alvarez, Beatriz Boned, Sverre Sandberg, Aasne K. Aarsand, Anna Carobene, Pilar Fernandez-Calle, Abdurrahman Coskuun. Ikke til stede: Federica Braga, Berna Aslan, Xavier Tejedor,Joana Minchinela, Craig Webster. Foto: European Federation of Laboratory Medicine and Clinical Chemistry

Den aktuelle studien i Clinical Chemistry brukte den utviklede standarden til å evaluere biologiske variasjonsstudier for 28 vanlige laboratorieanalyser identifisert ved hjelp av systematisk litteratursøk. Resultatene viste at mange studier er av for dårlig kvalitet eller har utdaterte resultater. Arbeidsgruppen har også utviklet en metaanalysemetode til å lage felles biologisk variasjonsestimat basert på studier av akseptabel kvalitet.

Studien utgår fra to internasjonale arbeidsgrupper i European Federation of Laboratory Medicine and Clinical Chemistry, som ledes av henholdsvis Aarsand og Sverre Sandberg. Arbeidsgruppene består av forskere fra syv land, og den aktuelle studien er resultat fra fire års arbeid. Den ene arbeidsgruppen har også etablert en stor biologisk variasjonsstudie med deltagere fra fem europeiske land.

Resultatene fra arbeidsgruppenes arbeid legges fortløpende inn i en offentlig tilgjengelig database (2), som ble lansert på en stor europeisk laboratoriekongress i Barcelona i mai 2019. Målet for arbeidet er å bidra til at biologisk variasjonsdata er korrekt og lett tilgjengelig for laboratorier verden over.

\section{LITTERATUR:}

1. Aarsand AK, Røraas T, Fernandez-Calle P et al. The biological variation data critical appraisal checklist: A standard for evaluating studies on biological variation. Clin Chem 2018; 64: 501-14. [PubMed][CrossRef]

2. The EFLM Biological Variation Database. http://www.biologicalvariation.eu Lest 31.10.2019. 